\title{
An Exploration of Human Rights and Social Work Education in the United States
}

\author{
Lori Sousa-Meixell $^{1}$ [D $\cdot$ Sook Hyun $\mathrm{Kim}^{2} \cdot$ Hiie Silmere $^{1}$
}

Accepted: 25 April 2021 / Published online: 30 July 2021

(c) The Author(s), under exclusive licence to Springer Nature Switzerland AG 2021

\begin{abstract}
Social work, with its commitment to social justice, knowledge about cultural diversity, and respect for the dignity and worth of the individual, has much to contribute to the modern-day human rights debate. Many international social work scholars have articulated the view of social work as a human rights profession. The profession's presence in this arena, however, has not always been apparent. Amid increasing global tensions and domestic challenges, equipping social work students with human rights knowledge and skills is critical. The limited attention given to human rights in social work education, particularly in the United States, provides a unique opportunity to explore the human rights discourse occurring in academic circles. This paper presents a review of scholarly journal articles that explore the human rights discourse related to social work education in the United States. Upon reviewing the literature, the following categories emerged: (1) general articles on integrating human rights into social work education; (2) pedagogical frameworks, models, and examples of incorporating human rights into social work education; and (3) measures and perceptions related to assessing the integration of human rights in social work education. Findings indicate that the inclusion of human rights into social work education in the United States is in its infancy. It is recommended that social work programs in the United States be more intentional about integrating human rights content into the curricula to train culturally competent and globally minded social workers.
\end{abstract}

Keywords Human rights · Social work education $\cdot$ Social work $\cdot$ Social justice

Social work, with its commitment to social justice, knowledge about cultural diversity, and respect for the dignity and worth of the individual, has much to contribute to the modern-day human rights debate. Scholars have often articulated the view of social work as a "human rights profession" (Healy \& Thomas, 2020; Ife, 2012; Mapp et al., 2019; Reichert, 2011a). Androff (2018) argues that central social work documents, sources, organizations, and values clearly establish social work as a human rights-based profession. The concept of human rights as fundamental to social work practice is articulated in the following key documents: the International Federation of Social Workers Global Definition of Social Work (IFSW, 2014); the

Lori Sousa-Meixell

Sousa_lori@roberts.edu

1 Department of Social Work, Roberts Wesleyan College, Rochester, NY, USA

2 Department of Social Work, Salisbury University, Salisbury, MD, USA
"Global Agenda of Social Work and Social Development" (2014a) and the Educational Policy and Accreditation Standards (EPAS) put forth by the Council on Social Work Education (CSWE, 2008, 2015). The presence of human rights in social work, however, has not always been apparent. The limited attention given to human rights in social work education, particularly in the United States, warrants further investigation.

This paper presents a review of scholarly articles exploring the current state of the human rights discourse related to social work education in the United States. It compels educators toward a critical and thoughtful integration of human rights into social work curricula. Before presenting the findings from the literature, the paper provides a context for the inclusion of human rights in social work education by examining the development of the Universal Declaration of Human Rights (UDHR), its implementation in the United States, and the presence and practice of human rights in the field of social work in general. 


\section{The Development of Universal Human Rights}

The evolution of the integration of human rights in social work education in the United States must be understood in the historical and cultural context. Since its inception, the establishment of the UDHR was fraught with challenges as the Committee on the Theoretical Bases of Human Rights, established by the United Nations Educational, Scientific, and Cultural Organization (UNESCO), sought to navigate conflicting ideologies, cultures, and interests (UNESCO, 1949). After the UDHR was adopted by the United Nations (UN) General Assembly in 1948, the focus remained on establishing a covenant to specify rights and limits. After much debate, the decision was made to draft two covenants on human rights: (1) the International Covenant on Civil and Political Rights (ICCPR) (United Nations General Assembly, 1966), and (2) the International Covenant on Economic, Social and Cultural Rights (ICESCR) (United Nations General Assembly, 1966). The ICCPR (contained in articles 3-21 of the UDHR) pertains to civil and political rights. These rights are strongly individualistic. The intent of these rights is the protection of the individual against state interference. The rights contained in the ICCPR find their basis in the United States Bill of Rights adopted in 1789, and the Declaration of the Rights of Man and Citizens adopted in 1793 (Ife, 2012). The articles in the ICCPR resonate with the rights encoded in the laws and values of the United States. The ICESCR (contained in articles 22-27 of the UDHR) refers to economic, social, and cultural rights. These rights prohibit the state from denying access to basic socio-economic needs. The articles also oblige states to take measures to improve the overall social situations of their citizens. The set of rights encoded in the ICESCR focuses on the equal condition for, and treatment of, citizens. US citizens are less familiar with the rights contained in the ICESCR, as these values resonate less with US culture and laws (Ife, 2012).

The complexity of codifying universal human rights is underscored by the fact that it took close to 30 years from the time the UDHR was adopted before the UN would ratify the ICCPR and ICESCR. The creation of the two Covenants had to overcome many hurdles. In the decades following the passage of the UDHR, the world witnessed revolutionary shifts in economic, social, and cultural thinking. Following World War II, much of the world was divided into two major competing economic and political systems-capitalism/socialism and democracy/communism. Over the years, post-modern thinking and cultural relativism emerged, and the study of cultural diversity gained popularity in Western cultures. With the shift toward cultural relativism, positivism, and universal values became suspect. All of this, coupled with the counterculture of social and political revolutions of the 1960s, contributed to the immense challenge of defining the specific universal human rights that would eventually be encoded in the ICCPR and ICESCR. After the UN General Assembly ratified the ICCPR and the ICESCR in 1976, the two documents were widely accepted and ratified by most countries with some notable exceptions. The former Soviet Union refused to support the ICCPR, arguing that economic rights must precede political and civil rights. The United States refused to ratify the ICESCR, claiming the economic, social, and collective rights implied a commitment to socialism (Gomez Isa \& de Feyter, 2006).

The brief history of the development of the UDHR highlights the tremendous impact culture has on decisions about human rights. Most significantly, close to 30 years after the UN General Assembly ratified both Covenants, the United States has only ratified the ICCPR. Articles on economic, social, and cultural rights contained in the ICESCR have been ratified by 171 nations as of 2020 (United Nations General Assembly, 1966). Even though the United States signed this portion of the International Bill of Rights in 1977, it stands out as the only developed country that has not ratified it (Ife, 2012; McPherson, 2018). Since the UDHR's initial documents, the UDHR has evolved to include additional treaties. Presently, nine international treaties further elucidate the principles of the UDHR, of which the United States has only ratified three (McPherson, 2018; Wronka, 2017). It is worth noting that, in addition to the ICESCR, the United States has not ratified the following international covenants: the Convention on the Elimination of All Forms of Discrimination Against Women; the Convention on the Rights of the Child; the International Convention on the Protection of the Rights of All Migrant Workers and Members of their Families; the Convention of the Rights of Persons with Disabilities; and the International Convention for the Protection of All Persons from Enforced Disappearance (McPherson, 2018; Wronka, 2017).

The awareness around the development of the UDHR, its covenants, and the historical context in which these documents emerged provides a necessary context for understanding the human rights discourse in the field of social work.

\section{Human Rights and Social Work}

In 1928, the First International Conference of Social Work was held in Paris. This meeting gave birth to the International Association of Schools of Social Work (IASSW) and the International Council on Social Welfare (ICSW) (Healy \& Link, 2012). It also led to the creation of the International Federation of Social Workers (IFSW) (Healy \& Link, 2012). Twenty years later, in 1948, the UN General Assembly 
ratified the UDHR (United Nations General Assembly, 1948). Social work was involved in human rights before the creation of the UDHR, but the profession had little visibility in this area until the 1970s (Healy, 2008). Healy (2008) notes that in 1988 the IFSW issued the following policy statement:

Social work has, from its conception, been a human rights profession, having as its basic tenet the intrinsic value of every human being and as one of its main aims the promotion of equitable social structures, which can offer people security and development while upholding their dignity. (pp. 735-736)

Given the global significance of human rights issues in social work, the IFSW (2018) has incorporated human rights into its Statement of Ethical Principles. The prominence of human rights is further demonstrated by the Council on Social Work Education, who made human rights a core competency in the 2008 EPAS (CSWE, 2008). The 2015 EPAS made additional progress by charging social workers with advancing human rights and promoting social, economic, and environmental justice (CSWE, 2015, p. 7).

During the past decade, social work has made significant strides in providing professional leadership and clear strategies in the area of human rights. The collaborative efforts of the IASSW, ICSW, and IFSW to launch the "Global Agenda for Social Work and Social Development" ("The Agenda") ${ }^{1}$ provides social work with a unifying focus and an explicit strategy for pursuing sustainable development and global respect for human rights. According to Truell \& Jones (2017), The Agenda aims to utilize social work practitioners' experience and skills in policy development to achieve sustainable, collaborative outcomes to address highly complex problems created by increasing inequality. Each step in The Agenda's development has "been a significant milestone on a journey that will continue to reposition social work in advocating for social policy based on social justice and human rights" (Truell \& Jones, 2017, para 42). Additionally, in 2015 the global community at the UN endorsed the 2030 Global Agenda entitled "Transforming our World: The 2030 Agenda for Sustainable Development" (United Nations, 2015). The global agenda of Sustainable Development Goals (SDGs) replaces the Millennium Development Goals (MDGs) and provides social workers with the opportunity to work collaboratively, inclusively, and strategically with the global

\footnotetext{
1 The "Global Agenda for Social Work and Social Development: Commitment to Action" was published in 2012. Since then, The Agenda's evolving platform has been articulated in four additional publications. The first report (2014) promoting social and economic equalities; the second report (2016) promoting the dignity and worth of peoples; the third report (2018) promoting community and environmental sustainability; and the fourth report (2020) strengthening recognition of the importance of human relationships.
}

community to address a comprehensive range of human rights issues. According to Jayasooria (2016),

Adopting a human rights approach to social work practice is of utmost importance as it is founded on the inalienable rights of the human person. The SDG global agenda enables social workers to utilize this approach based on the global commitment through the 2030 agenda, which is focused on development, human rights, and the environment. (p. 19)

The endorsement of The Agenda and the SDGs provide social workers with the opportunity to reevaluate their role in socio-economic development and their application of a human rights perspective.

With regard to the perception of human rights in social work, original conceptions of human rights within the profession focused on universal freedoms valued by virtually all people (Levin, 2009). The human rights discourse in social work also focused on how freedoms are affected by various aspects of identity and environment (Ife, 2012). According to Reichert (2011a), even though several population-specific definitions of human rights have arisen over the years, the most useful and enduring reference is outlined in the UDHR where human rights are defined as those rights which are inalienable and inherent in all human individuals by virtue of their humanity alone. According to the UDHR, all human beings are born equal in dignity and rights.

Wronka (2017) points out five major dimensions contained within the UDHR, including (1) dignity; (2) nondiscrimination; (3) civil and political rights; (4) economic, social, and cultural rights; and (5) solidarity rights. Wronka's analysis of the UDHR has influenced how many social work institutions define human rights (Steen et al., 2017). Wronka and Franklin (2019) also articulates human rights as a set of interdependent guiding principles that can be understood best with the UN Human Rights Triptych. The Human Rights Triptych consists of the UDHR (international law) on the center panel, the guiding principles (the declarations and conventions following the UDHR) on the right panel, and the implementation mechanisms on the left panel. The implementation mechanisms are comprised of monitoring mechanisms such as the world conferences and the Universal Periodical Review (UPR) of the Human Rights Council (HRC).

Rather than applying human rights to limited areas of social work, Wronka argues that human rights, taken as a whole, is most amenable to advanced generalist practice. According to Wronka, human rights can serve as the guiding principles for the social work curriculum at the global (meta-macro), whole population (macro), at-risk (mezzo), clinical (micro), everyday life (meta-micro) levels. Wronka envisions the advanced generalist approach as an essential component in creating a human rights culture in social work 
education. An advanced generalist practice approach encourages a proactive integration of human rights into all areas of social work. It also fosters collaboration with other professions that aim to eradicate social problems.

Another framework that has been used in social work to broaden the idea of human rights is a classification system developed by Czech jurist Karel Vasak in 1977, whereby universal human rights are divided into three generations (Hokenstad et al., 2013; Ife, 2009; Reichert, 2011a). The first generation lists political and civil rights that pertain to individual freedoms. The second generation of rights contains economic, social, and cultural rights to ensure everyone has an adequate living standard. The third generation of rights includes a set of collective rights requiring intergovernmental cooperation on issues such as economic development and environmental protection. For social workers, the three-generation approach expands and operationalizes the rights of individuals. In many ways, it is an ideal model for addressing some of the most pressing domestic and international issues. Ife (2012) states:

When people in western societies talk about human rights, they often mean first-generation civil and political rights...In social work, this leads to a view of human rights work as the domain of only a minority of social workers, whereas the inclusion of secondand third-generation rights would effectively define all social workers as doing human rights work. (pp. 48-49)

Another way to understand human rights is from a bottomup perspective, in which human rights are understood from firsthand experiences, and individuals are recognized as experts in their own lives (Hodge, 2010; Ife, 2009). These approaches contrast with the top-down approach of the UN.

Despite the utilization of pluralistic definitions of human rights, the UDHR's definition of human rights forms the basis for understanding various approaches to this subject. Any perspective that disregards or violates fundamental human rights as described in the UDHR is considered contrary to the principles of human rights.

When considering the integration of human rights in social work education, it is essential to acknowledge the cultural biases toward human rights that exist in the American psyche. Human rights scholars argue that social work education in the US prioritizes social justice concepts over human rights, limiting students' understanding of important human rights documents and norms (Mapp \& Gatenio Gabel, 2019). If, however, social work programs in the US are committed to human rights education, social work educators must be intentional in their efforts to expose students to all international human rights treaties that comprise significant components of the UDHR. Economic, social, cultural, and solidarity rights should be given particular focus as the United States grapples with significant modern-day challenges. Most notable are the heightened awareness of racial oppression, the impact of the COVID-19 pandemic, increasing economic disparities, and various other socioeconomic difficulties that face our nation. Social work education programs must give concerted attention to the full range of fundamental human rights to meet these challenges and harness the opportunities of greater global interdependence. Consequently, social work educators must consider ways in which human rights can be incorporated into the curriculum.

\section{Methods}

To gain insight into the discourse on integrating human rights in social work education in the United States, we searched two databases that are likely to be used by social work educators: Social Work Abstracts and PsycINFO. We narrowed down our search to peer-reviewed journal articles published in the last 72 years (1948-2020), dating back to the signing of the UDHR. The search terms included human rights AND educat* OR curriculum. We added the search term social work in the PsycINFO database to narrow down the search to human rights issues pertaining specifically to the social work discipline. Finally, we also reviewed the table of contents of the first five volumes of the Journal of Human Rights and Social Work published between March 2016 and March 2020.

The findings yielded 61 articles in the Social Work Abstracts and 248 articles in the PsycINFO database that matched the search criteria. We scanned through the titles and abstracts of these sources to identify those that appeared to be directly relevant to human rights issues in the context of social work education in the United States. This process yielded 15 relevant articles from the Social Work Abstracts database and 14 articles from the PsycINFO database. Since two of these articles appeared in both databases, it resulted in a sample size of 27 articles from our database search that related to the topic. Additionally, five articles were identified from the Journal of Human Rights and Social Work, making the final sample size for this literature review 32.

Upon reading all 32 articles, three main categories emerged based on the articles' primary focus or content area. Some of the articles addressed multiple categories. The first category included general articles that contained information on the need to integrate human rights into social work education in the United States. The second set of articles focused on pedagogical frameworks, models, and examples of how to incorporate human rights into social work education. Finally, the third category of articles focused on measures and perceptions related to assessing the integration of human rights in social work education and how human rights 
can be understood in the social work context. The next section provides a more detailed overview of findings related to articles in each of these three categories.

\section{Findings}

\section{General Articles}

Eight of the 32 articles discussed the general need to integrate human rights into social work education in the United States (Chiarelli-Helminiak et al., 2018; "Global Agenda," 2014b; Healy \& Wairire, 2014; Pelton, 2001; RichardsDesai et al., 2018; Reichert, 2011b; Steen, 2006; Witkin, 1998). Witkin (1998) argues that human rights are integral to the mission of social work. Likewise, Steen (2006) asserts that social workers are called to protect and promote human rights as part of their professional duties. Despite the desire to include human rights in social work education, many authors highlighted significant challenges. Scholars point out that the application of human rights to social work practice in the United States remains in infancy, with many practitioners lacking formal instruction in this area (Chiarelli-Helminiak et al., 2018; Reichert, 2011b; RichardsDesai et al., 2018). There is a lack of understanding and consensus on human rights within the social work profession due to the ambiguity surrounding the teaching of human rights. It is also argued that the human rights curriculum in the United States needs to be strengthened to engage social work students and faculty in understanding and implementing the "Global Agenda" (2014b) commitments. Healy and Wairire (2014) make a case that more curriculum emphasis on social and economic development, human rights, and social integration is needed. Scholars also draw attention to the fact that current global and local standards for the social work curriculum do not require or even recommend coverage of the international instruments specified in the Global Agenda for Social Work and Social Development (Chiarelli-Helminiak et al., 2018; Healy \& Wairire, 2014; Richards-Desai et al., 2018).

Stark contradictions and ambiguity exist around teaching human rights and its relationship to social justice (ChiarelliHelminiak et al., 2018; Pelton, 2001; Richards-Desai et al., 2018). Even though the National Association of Social Workers (NASW) endorses human rights in policy statements, human rights are not explicitly addressed in the professional code of ethics. Instead, human rights are implied under the "social justice" value (Ife, 2012; Richards-Desai et al., 2018). A recent study also suggests that many social work educators place human rights and social justice in the category of "macro social work" (Chiarelli-Helminiak et al., 2018). Therefore, due to the dominant micro-frame within social work in the United States, the teaching of human rights and social justice are marginalized in the social work curriculum.

Additionally, there are unique cultural challenges that impact the teaching of human rights in social work programs in the United States. Discourse on human rights in the US has emphasized civil and political rights at the expense of social, cultural, and solidarity rights (Reichert, 2011b). Chiarelli-Helminiak et al. (2018) identify what they refer to as an "American exceptionalist" stance that impacts the perception of human rights. They argue that students and educators often view human rights violations as relevant to other countries but not to the US. Both the disproportionate emphasis on civil and political rights and the phenomenon of American exceptionalism transfer to the classroom. "The Global Agenda for Social Work and Social Development" (2014b) discusses initiatives of national social work organizations in North America to actively promote social and economic equalities through a range of strategies and commitments. As part of this process, strengthening the human rights curriculum in the United States is a critical first step in engaging students and social work practitioners in understanding and implementing the Global Agenda commitments (Healy \& Wairire, 2014).

Aside from the lack of formal instruction and the cultural impacts that influence perceptions of human rights, social work educators in the United States face the added logistical challenge of giving adequate time and attention to human rights in the social work curriculum. The ambiguity surrounding the integration of human rights in social work impacts the knowledge and skills educators have in this area; this, in turn, affects the preparation of future social workers. Social work educators are challenged to find room for human rights content in social work education. They also often lack the necessary resources or training in this area. Chiarelli-Helminiak et al. (2018) argue, "The challenge to fit all the content needed to train competent, effective social work practitioners point to broader debates about what constitutes the state of the field and necessary competencies for social work practitioners in the twenty-first century" (p. 102). Even if social work programs are committed to integrating human rights in their curriculum, they may face ideological and logistical challenges.

Most of the articles in the general category contain preliminary suggestions for including human rights content in social work courses. Authors argue that educators must intentionally expose students to the full range of human rights in coursework and practice settings ("Global Agenda," 2014b; Healy \& Wairire, 2014; Reichert, 2011b). Some educators have even voiced the need for systemic institutional change in the profession that extends to licensure requirements (Chiarelli-Helminiak et al., 2018). 


\section{Pedagogical Frameworks, Models, and Examples}

Twenty-two of the 32 articles contains suggestions for how to integrate human rights into social work education (Acquaye \& Crewe, 2012; Barbera, 2006; Chiarelli-Helminiak et al., 2018; Davis \& Reber, 2016; Gammonley et al., 2013; Gardella, 2000; Hawkins \& Knox, 2014; Hodge, 2007, 2010; Kaiser et al., 2015; Lewis et al., 2016; McPherson \& Cheatham, 2015; McPherson \& Mazza, 2014; Melekis \& Woodhouse, 2015; Nesmith \& Smyth, 2015; Patterson, 2004; Reichert, 2011b; Richards-Desai et al., 2018; Steen \& Mathiesen, 2005; Steen et al., 2017; Witkin, 1994, 1999). Many of the articles provided examples or case studies where a human rights integration model was used. For social work programs wishing to include a greater emphasis on human rights, scholars suggest a few frameworks through which learning can occur. Hawkins and Knox (2014) present a global citizenship framework that emphasizes a student's position within a worldwide community. This framework focuses on three areas: literacy, empathy, and responsibility. First, a student must be made aware of an issue and learn some foundational information about it. Next, a student needs to feel the problem's impact, whether through a personal connection or an emotional experience. Finally, action is likely to be taken once a student realizes their responsibility to their fellow citizens. In other words, as a student learns about a human rights issue, they feel the impact of the issue emotionally and recognize their responsibility to influence the matter. Figuratively speaking, the issue moves from the head to the heart to the hands. Taking action and positively impacting a problem helps create skilled practitioners, advocates, and future leaders in the field (Hawkins \& Knox, 2014).

Several authors advocate for similar frameworks emphasizing a connection between cognition and affect. For example, Gammonley and colleagues (2013) describe the experience of students and professionals, who, upon learning about a human rights issue, began to develop empathy, which inspired them to act. A similar connection was made by McPherson and Mazza (2014), who described the use of art to teach students about human rights violations. The authors describe a process in which students engage creatively with a project involving human rights. As they work on the project, they gain empathy. Their awareness then leads to initiative and action. The use of reflection is a crucial element, as it encourages students to consider human rights issues that they are unfamiliar with, which increases empathy and spurs motivation (Acquaye \& Crewe, 2012; Kaiser et al., 2015; Witkin, 1999).

Scholars further suggest that a connection can be made to human rights issues that reflect students' experiences and career goals (Acquaye \& Crewe, 2012; Hawkins \& Knox, 2014). Often there is a disconnect between educational content and career goals that diminish student motivation or interest in a given topic. Instructors and students can benefit if explicit connections can be established between a student's professional goals and curricular content. A student may become further motivated if an issue can be shown to be similar to that student's experiences. For example, Acquaye and Crewe (2012) suggest that oppression and racially motivated violence in other countries can be associated with the ongoing struggle against racism in the United States. By connecting the local context to the global struggles or vice versa, students can make a personal connection based on experience and emotion, making them more driven to pursue change and hopefully become more skilled practitioners in the future (Hawkins \& Knox, 2014).

Hodge (2010) suggests a slightly different, albeit complementary social justice pedagogy, in which human rights are conceptualized primarily as an underlying aspect of social justice. Within this framework, social justice is understood through epistemic pluralism, client-centered conceptualizations of social justice, and fundamental human rights. By adopting a pluralistic, bottom-up approach, social justice issues are understood in a more flexible framework that can be tailored directly to the experiences of oppressed populations. Human rights are then considered in light of others' experiences, in concert with the UDHR acting as the primary defining authority of what constitutes fundamental human rights.

Additional teaching strategies have demonstrated potential efficaciousness. Six of the 32 articles reviewed suggest using specific issues as a framework to introduce the broader topic of human rights in social work education (ChiarelliHelminiak et al., 2018; Hodge, 2007; Kaiser et al., 2015; McPherson \& Cheatham, 2015; Nesmith \& Smyth, 2015; Patterson, 2004). Each of these initiatives broadens students' understanding of a given social justice topic while providing useful frameworks to discuss other issues in the field. These initiatives include discussions on how the given social justice topic relates to human rights. Many of these articles suggest classroom activities to engage students in issue-based advocacy to increase their awareness about human rights.

For example, Patterson (2004) focuses on social justice issues affecting the older adult population. Students are encouraged to adopt a strengths-based approach while also focusing on human rights impacting older people. Nesmith and Smyth (2015) focus on environmental justice as a human right. They discuss climate change and environmental degradation as the most significant threat to human health and advocate for social work to take the initiative on this aspect of human rights. They also argue that the degradation of life-sustaining resources is a threat to all humanity. Kaiser et al. (2015) discuss food security as an essential issue. They state that social work educators are responsible for teaching a curriculum that compels students to advance human rights, social justice, and economic justice. They also provide examples of assignments that can be used to educate 
students about food and environmental justice issues. McPherson and Cheatham (2015) describe the integration of human rights with a national arts-activism initiative. They recount an effort to include students in an advocacy project addressing human rights violations of genocide and mass violence. As part of this advocacy project, McPherson and Cheatham also assess student engagement and exposure to human rights. Finally, Hodge (2007) focuses on the violation of religious freedom as a human rights issue and argues that violations of religious rights must be addressed in the context of international human rights abuses.

\section{Integration into Existing Courses and Curricula}

One practical but underutilized method to teach social work students the human rights perspective is to integrate human rights material into existing courses or curricula. One study found that most social work programs in the United States (91\%) had no identifiable human rights course (Steen \& Mathiesen, 2005). Some social work programs, however, including Fordham University, Monmouth University, and the University at Buffalo, have integrated human rights across their curriculum (Chiarelli-Helminiak et al., 2018). Richards-Desai et al. (2018), for example, describe the University at Buffalo School of Social Work's adoption of human rights as a guiding framework for its MSW program. They detail the development of the program's curriculum based on a human rights perspective. Primary activities utilized in the transformation of the program included faculty discussions and retreats. The discussions and retreats incorporated strategic goals and aimed to harness the faculty's unique strengths and interests. The program revised its mission statement and utilized an infused model to integrate human rights content into all courses. The goal was to focus on applying a human rights perspective by providing theoretical and practical skills at all levels of social work practice.

With field education designated as the signature pedagogy for social work, field placements also provide an ideal opportunity for students to contextualize their work at agencies through a human rights framework (Barbera, 2006; Davis \& Reber, 2016; Lewis et al., 2016; Steen et al., 2017). In this context, students can hear of the experience of practicing social workers, gain professional skills, and begin to apply human rights concepts to practice settings. Steen et al. (2017) identify several themes based on responses from interns and supervisors who participated in human rights-practice-based internships. These included the importance of advocacy in human rights practice, service provision as a micro-level human rights concept, the importance of assessment, the importance of rapport and relationship between provider and client, and an awareness of threats to clients' human rights.
Several scholars suggest that social work programs can benefit from integrating human rights into student learning contracts at their internship sites (Davis \& Reber, 2016; Lewis et al., 2016). Lewis and colleagues recommend the use of a broad perspective when incorporating human rights practice in internships. This broad perspective allows agencies the needed flexibility in crafting the learning experience. Davis and Reber suggest that well-planned learning contracts offer students the necessary foundation for implementing a rights-based approach to field education. With the support of field faculty, students can craft learning contracts that analyze the relevant human rights issues at their agency, identify ways to advocate on behalf of clients, and engage in efforts that directly help client systems. When assessing the learning agreements of four cohorts of BSW students, Davis and Reber found that by attending to human rights, many students were forced to grapple with macro systems impacting their clients' lives. Since clear contracts guide field education, Davis and Reber emphasize the importance of supporting students to stimulate critical thinking when crafting the learning contract. Instructors can encourage students to think about human rights issues impacting clients in their field placement. They can also support students in identifying practices and policies that advance human rights. Additionally, Davis and Reber suggest that social work programs can provide training for field instructors on how to support students to develop practice behaviors that promote the advancement of human rights.

Topics related to human rights could also be integrated into courses on the micro-, mezzo-, and macro-level (Steen et al., 2017). Reichert (2011b) suggests that human rights can be integrated into micro-level clinical practice courses by focusing on the human rights of individual clients. McPherson and Mazza (2014) argue that creative projects related to human rights can be integrated into existing policy courses. Melekis and Woodhouse (2015) describe a class in which food justice and sustainability were successfully integrated into an existing Practice II course. In addition, Witkin (1994) argues for integrating human rights in social work research and suggests teaching a human rights approach to research. Likewise, Kaiser et al. (2015) suggest that instructors can incorporate human rights into research classes by engaging in program and service analysis of existing agencies. The aforementioned global citizenship framework proposed by Hawkins and Knox (2014) in which literacy, empathy, and responsibility are emphasized, can also be integrated into existing courses.

\section{Service-Learning}

Another trend in the literature is the use of service-learning to teach students the human rights perspective. This learning can take place on either the international or local level. 
Examples of international service-learning opportunities are described by several studies (Acquaye \& Crewe, 2012; Gammonley et al., 2013; Witkin, 1999). A group of African American social work students from Howard University participated in a unique international service-learning opportunity in South Africa that taught them about human rights and provided a meaningful connection to issues that concerned students (Acquaye \& Crewe, 2012). Through this opportunity, students were able to examine the historical and practical implications of human rights violations in South Africa and understand how these relate to human rights violations occurring elsewhere in the world. This project also helped students learn about existing service needs and enabled them to contribute to the development of new strategies to improve service delivery and protect the human rights of citizens both at home and abroad.

Another study describes a group of delegates, including social work students, who traveled to Guatemala to hear the testimony of women who endured terrible acts of violence (Gammonley et al., 2013). Students collected data on various issues facing these women and used this information to identify needs, analyze policies, and advocate for change. This experience helped student delegates learn about the human rights perspective and develop practice skills. Students were also better able to understand the cultural and environmental context in which clients find themselves, allowing for a synthesis between the person-in-environment approach and a human rights perspective. Here, the importance of understanding the interaction between social problems, policy initiatives, legal issues, and international strategies for change promotes both education and action.

Finally, Witkin (1999) describes an international seminar for social work students from several countries, including Finland, Spain, the USA, Estonia, Lithuania, Latvia, Romania, and Germany. Instructors, rather than providing students with facts, encourage discussion and reflection on a wide range of topics such as the artificial nature of borders, HIV/ AIDS, poverty, and pollution. Conversation and contemplation contribute to a new understanding of social work practice within a global community.

International opportunities provide many benefits for social work students, but the cost and time required may be prohibitive. As such, local service-learning opportunities and internships can be more practical tools to teach students how to understand and advocate for human rights. These experiences can increase students' understanding of the struggles of underserved, oppressed populations (Kaiser et al., 2015).

\section{Collaborations}

The literature notes the significance of using community, interdisciplinary, and international collaborations to aid in human rights education. Community collaborations are essential to forging successful service-learning experiences. Partnerships between schools of social work, community agencies, and other disciplines are necessary to strengthen the student experience (Kaiser et al., 2015). Cooperation and the use of community assets increase a social work program's relevance to its community and provide an understanding of the issues which are pertinent to the community (Lewis et al., 2016). However, one of the challenges educators have to navigate when collaborating with outside organizations involves issues of power differentials within the community. These power differentials can occur between the university and other organizations or community members (Gammonley et al., 2013; Lewis et al., 2016). For example, issues of paternalism may arise depending on how local or international community members are compensated for their involvement in the program. In addition to these challenges, Lewis and colleagues note that there are also few existing protocols for collaborative efforts.

In addition to community collaborations, interdisciplinary cooperation can be used as another helpful tool for social work programs seeking to include more human rightscentric curricular content (Melekis \& Woodhouse, 2015). By seeking input from other related disciplines, such as nutrition professors for course content related to food justice issues, or economics professors on matters related to poverty, professors can improve the quality of instruction and ensure competence consistent with the NASW (2017) Code of Ethics.

International collaboration is also noted as a valuable tool for social work programs. When discussing the usefulness of the global community framework, Hawkins and Knox (2014) mention that it is helpful for students to re-conceptualize themselves as members of a global family. This framework is consistent with the preamble of the UDHR (United Nations General Assembly, 1948), in which equal rights and dignity are afforded to every member of the human family. Helping students understand and embrace this perspective is an essential aspect of human-rights-based social work education and can be fostered partially through international community cooperation. Programs can also partner with international non-governmental organizations (NGOs) to facilitate international service-learning opportunities. These partnerships can provide useful information about ongoing human rights issues, policy positions, and local opportunities to advocate for global change (Acquaye \& Crewe, 2012; Gammonley et al., 2013). International cooperation with agencies can help students learn and discuss human rights issues that different populations may be facing (Witkin, 1999). Collaboration with these agencies can generate new ideas and expand students' concepts of their place in the global family. For example, programs can partner with other international schools allowing students to interact with one another and gain a more global perspective (Hawkins \& Knox, 2014). Interactions can be 
as simple as email correspondence throughout the semester, which may eventually lead to teleconferences or video calls.

\section{Specific Educational Methods}

Several other educational tools for integrating human rights into social work education are mentioned in the literature. Role-plays and simulations can allow students to step into the shoes of the oppressed and increase their understanding of individuals who have dealt with human rights violations (Hawkins \& Knox, 2014; Kaiser et al., 2015). Interviews can also be useful educational tools to help students develop empathy and understanding (Hawkins \& Knox, 2014). Similarly, students can listen to the firsthand testimony of victims whose human rights have been violated. However, both listening and interviewing require that students have some basic prior knowledge of the issues to be addressed (Gammonley et al., 2013). Students can also interact with various forms of media, such as film, music, art, and literature, to gain further insight into human rights issues. Several studies have cited the effectiveness of utilizing these mediums to promoting empathy (Hawkins \& Knox, 2014; Patterson, 2004). For example, when reading Bontemps' short story, A Summer Tragedy, students expressed feelings of anger when characters were subjected to injustice and human rights violations. Students also reported feelings of joy when characters overcame those challenges (Patterson, 2004).

\section{Perceptions and Measures}

Finally, five of the 32 articles focused on measures and perceptions related to assessing the integration of human rights in social work education. These articles also provide information on how human rights can be understood in the social work context (Chiarelli-Helminiak et al., 2018; Davis \& Reber, 2016; McPherson \& Abell, 2012; McPherson et al., 2017; Richards-Desai et al., 2018). Perceptions of human rights in social work education in the United States are grounded in the belief in the inherent dignity and worth of the human being. Human rights are often linked to social justice, with both constructs being vaguely defined and intensely debated. Social work literature advocating for more focus on human rights tends to emphasize various aspects of human rights. Despite the CSWE (2015) EPAS standard to incorporate human rights in social work education, the lack of consensus around a foundational framework for a human rights-based approach in social work is lacking. Frequently, the proclivity for integrating human rights into course material varies by instructor. Chiarelli-Helminiak et al. (2018) suggest a positive relationship between faculty interest in human rights and the inclusion of human rights in their curriculum. Therefore, instructors' interest in human rights and their perception of specific aspects of human rights is a significant determinant of if and how a rights-based approach is introduced in social work courses. Richards-Desai et al. (2018) found a similar phenomenon. In their study of an MSW program that adopted a human rights framework, faculty interest and teaching approaches to human rights varied widely. They found that faculty encountered difficulty in achieving comfort and consistency when integrating human rights into course content. Some faculty questioned whether the curriculum was clear to everyone. One faculty member also noted the program's dilemma of navigating academic freedom and directives to incorporate a human rights approach.

Another significant contribution to the human rights scholarly literature is the development of measures and scales to assess the integration of human rights in social work. Three articles discussed the importance of measuring human rights integration in social work education and proposed theoretical frames or methods for assessing the quality of human rights education in social work (Davis \& Reber, 2016; McPherson $\&$ Abell, 2012; McPherson et al., 2017). Both qualitative and quantitative methods can be employed to assess human rights integration in social work education. With regard to quantitative methods, the following three scales have been validated: (1) Human Rights Lens in Social Work Scale (HRLSW) (McPherson et al., 2017); (2) Human Rights Exposure in Social Work Scale (HRESW) (McPherson \& Abell, 2012); and (3) Human Rights Engagement in Social Work Scale (HRXSW) (McPherson \& Abell, 2012).

The HRLSW is an 11-item scale designed to measure social workers' ability to see individual and social problems as resulting from human rights violations (McPherson et al., 2017). The scale consists of two subscales: (1) clients seen as experiencing rights violations, and (2) social problems seen as rights violations. This scale is useful for assessing the prevalence of a human rights-based orientation to practice in social work. It is also valuable for evaluating the effectiveness of educational and training interventions aimed at increasing a rights-based orientation to social work practice.

The HRESW is a 25-item measure of human rights engagement (McPherson \& Abell, 2012). The construct of engagement is comprised of the following: (1) the belief in the relevance of human rights to the social work profession, and (2) the commitment to putting the principles of human rights activism into practice. This scale can be employed with social work students or practicing social workers. It is designed to assess beliefs about social work as a human rights profession and individual engagement in human rights activism. Finally, the HRXSW is an 11-item scale designed to measure a social worker's exposure to human rights principles (McPherson \& Abell, 2012). This scale is suitable for educators who want to assess student exposure to human rights in social work education. 
With regard to qualitative measures, Davis and Reber (2016) utilized data collected from BSW students' learning contracts to assess students' ability to develop knowledge, values, and practice skills in human rights and social and economic justice. The data collected consisted of the students' descriptions of activities and responsibilities that they planned to engage in around the three practice behaviors identified for advancing human rights and social and economic justice (Core Competency 2.1.5. of the 2008 EPAS) (CSWE, 2008). Data from this study were analyzed inductively using thematic analysis and coded for each practice behavior. Field education is designated as the signature pedagogy for social work. The field contract is where students are tasked with construing the theoretical concepts of human rights into practice skills. The field contract, therefore, provides educators and researchers with valuable insight into how well students are equipped to bridge the gap of knowledge and practice skills. Davis and Reber suggest that learning contracts are a rich source of information. By examining learning agreements, social work researchers and educators can gain insight into how well students can: (1) identify and understand relevant human rights issues at their agency, (2) articulate plans to advocate on behalf of and empower clients, and (3) express effective ways to engage in activities to improve clients' human rights.

\section{Challenges}

The literature review revealed three primary challenges regarding integrating, creating, and implementing a human rights approach in social work education programs in the United States. These three areas involve ideological challenges, logistical concerns, and the limits of the currently available research. The ideological challenges involve how human rights are viewed and interpreted. Several articles discuss how ambiguity surrounding the human rights discourse impacts its integration in social work programs (ChiarelliHelminiak et al., 2018; Reichert, 2011b; Richards-Desai et al., 2018). Some articles noted that there is a perception that human rights relate to international issues or are limited to macro social work (Chiarelli-Helminiak et al., 2018; Davis $\&$ Reber, 2016). Other scholars point to the confusion surrounding the relationship between human rights and social justice (Chiarelli-Helminiak et al., 2018; Davis \& Reber, 2016; Pelton, 2001; Richards-Desai et al., 2018). These two terms are often used interchangeably, without clear definitions, and relegated to macro social work. Many faculty are not familiar with human rights approaches or concepts, and these misconceptions trickle down to social work students. Social work education, in turn, informs the profession, with many social workers having a limited perception of human rights. The misconceptions surrounding human rights can even be observed in social work doctoral education in the United States. Chiarelli-Helminiak and colleagues found that "scant attention to the relevance of human rights in US social work doctoral education compounds the challenges of integrating human rights at all levels of education and practice" (p. 102). They provide the example of a doctoral student who wanted to focus her dissertation on human rights abuses. When approaching the faculty committee overseeing her studies, she was informed that her interest in human rights was not appropriate because this topic is not part of social work.

The ideological challenges observed in social work classrooms are compounded by the fundamental way that human rights are perceived in the United States. According to Wronka (2017), only an estimated $10 \%$ of US citizens have even heard of the UDHR. With the cultural preference for civil and political rights, the full range of rights contained in international treaties are neglected. Without a foundational framework for understanding the full range of human rights, the social work curriculum is often determined based on an individual professor's interest or experience (ChiarelliHelminiak et al., 2018).

In addition to ideological challenges, many practical and logistical barriers must be overcome to create a human rights-centered course or curriculum (Chiarelli-Helminiak et al., 2018; Lewis et al., 2016; Richards-Desai et al., 2018). Support from the program administration is essential, as is an awareness of existing institutional resources, professional development for faculty, and backing for curricular changes (Chiarelli-Helminiak et al., 2018; Kaiser et al., 2015). Support from other departments may also help, as human rights issues can relate to several academic disciplines. Although there are few case studies of integrating human rights into the social work curriculum, Richards-Desai and colleagues provide qualitative data on an MSW program that transformed their curriculum using human rights as their guiding principle. They assessed how students viewed the human rights curriculum and the degree of human rights content, awareness, and comprehension among students. Despite numerous faculty discussions, trainings, strategic goals, revisions to the program's mission statement, and curricular design, the results indicated that students who went through this MSW program did not demonstrate significantly higher scores on exposure to and engagement in human rights. These findings further underscore the significant challenges encountered by programs that attempt to integrate a human rights-based approach to their curriculum.

Along with institutional concerns, there are financial constraints that must be considered. New courses, particularly electives, need to be evaluated not only from the standpoint of content but also from the viewpoint of financial viability (Kaiser et al., 2015). Considerations include an estimate of the number of students needed to make the class financially 
feasible (Hawkins \& Knox, 2014; Patterson, 2004). Although the importance of international service-learning programs is also mentioned in the literature (Acquaye \& Crewe, 2012; Hawkins \& Knox, 2014; Witkin, 1999), such endeavors can be prohibitively expensive for many students. Local and international collaborations, which are useful educational tools, can also be cost-prohibitive. Such partnerships require added efforts on the part of the staff and faculty. Partnerships may also require technological or language competencies for international contact via telecommunications programs.

The available research is also limited in some respects. Small sample sizes are frequently used, limiting the generalizability of findings (Acquaye \& Crewe, 2012; Gammonley et al., 2013; Kaiser et al., 2015). Virtually all studies are qualitative, with minimal quantitative support available. There is little research detailing the effectiveness of specific efforts, such as integrating art or other multimedia into existing social work classes or programs to address human rights (McPherson \& Mazza, 2014). Finally, although local and international community collaboration is recommended, there is currently little information within the literature regarding the effectiveness of these approaches.

\section{Limitations}

This review of scholarly articles on human rights and social work education has several limitations. First, the search for relevant articles focused only on two electronic databases (Social Work Abstracts and PsycINFO), and the table of contents of the first five volumes of the Journal of Human Rights and Social Work published between March 2016 and March 2020. This limited scope may have overlooked relevant sources disseminated through other venues. The decision to focus on Social Work Abstracts and PsycINFO was based on the assumption that social work educators are likely to access these two popular databases as they search for materials to inform their teaching methods.

Second, the search process was narrowed down to the phrase "human rights" and, consequently, might have overlooked sources that lack this phrase. Using different terminology connected to human rights, such as social justice, environmental justice, etc., may have yielded additional sources. However, we argue that it is still imperative to frame such related issues under the umbrella term of "human rights" to increase students' awareness around this vital topic.

Third, this review focused only on peer-reviewed articles, the vast majority of which were published within the past ten years. Nevertheless, this review can serve as a foundation for educators and scholars who wish to understand the discourse on human rights and social work education in the United States. Future studies can build on this work by examining books, websites, and course descriptions from different social work programs around the country that address human rights in the context of social work education.

Finally, this literature review was limited to social work education programs in the United States. This decision was made due to the consideration of unique dynamics, such as the "American exceptionalist" stance, that impact the expression and understanding of human rights in the US. Future studies can explore the similarities and differences in teaching human rights content in social work programs worldwide.

\section{Implications and Conclusion}

Despite these limitations and challenges, integrating human rights into social work education is vital for the profession to stay relevant. Human rights are inherent to the profession of social work, providing a bridge that connects local and global issues (Acquaye \& Crewe, 2012; Healy, 2008). Culturally competent and globally aware social workers are becoming more of a necessity as the world becomes increasingly globalized and communities more diverse. Currently, the international community faces unprecedented challenges. To address these challenges, social workers will need to work collaboratively to secure human rights for all people. The global impact of the COVID-19 pandemic has exacerbated social and economic disparities. Issues of equitable access to healthcare, social protection, racism, discrimination, and other forms of inequality are human rights challenges that will require the skills and expertise of social workers. In these extraordinary times, social work education programs must give concerted attention to the full range of fundamental human rights and harness the opportunities of greater global interdependence. Consequently, social work educators must consider ways in which human rights can be incorporated into the curriculum. Integrating human rights content into existing curricula and courses or creating new courses specifically focusing on human rights would benefit students by preparing them for practice in the ever-changing field of social work.

This review furnished readers with various pedagogical frameworks, models, and examples for the integration of human rights into social work education. The study suggests that using human rights as a paradigm in social work curriculum or courses can expose students to a variety of relevant topics, such as issues of diversity (Acquaye \& Crewe, 2012; Gammonley et al., 2013; Hawkins \& Knox, 2014); social justice (Hodge, 2010); violence (McPherson \& Mazza, 2014); environmental justice (Kaiser et al., 2015; Melekis \& Woodhouse, 2015); and issues involving the older adults (Patterson, 2004). Such an approach can have practical benefits for students by connecting real-life issues to 
career goals and better preparing students for real-life practice and employment (Acquaye \& Crewe, 2012; Lewis et al., 2016). By learning about human rights and connecting this approach to local issues, students will begin to broaden their perspectives on human rights. They will start to see current challenges in the United States through a human rights perspective. Issues such as exorbitant health care costs, poverty, homelessness, disability, unemployment, food scarcity, and racial inequality can be evaluated through a human rights lens. Additionally, students who engage in some type of policy or change advocacy centered around human rights may also find that the change process becomes a bit more feasible (Hawkins \& Knox, 2014).

Another significant contribution has been the development of scales to assess various aspects of human rights in social work (McPherson \& Abell, 2012; McPherson et al., 2017). These validated scales help educators and scholars develop an evidence-based approach to human rights practice in social work. In addition to the scholarly articles summarized in this review, multiple books have been published to aid social work educators and students in developing competencies in human rights practice (e.g., Androff, 2016; Clapham, 2015; Healy \& Link, 2012; Hertel \& Libal, 2011; Hokenstad et al., 2013; Ife, 2009, 2012; Kosher et al., 2016; Mapp, 2020; Maschi, 2016; Reichert, 2011a; Wronka, 2017).

Regardless of what methods are employed, the CSWE (2015), the NASW (2018), and the IFSW (2018) make it clear that teaching social work students about human rights issues is imperative for the future of the field. Based on this directive, there is a need to integrate a human rights perspective into social work education (Hawkins \& Knox, 2014). As one student put it, "human needs are the same everywhere you go-the problem comes in when societal members place no value on human rights" (Acquaye \& Crewe, 2012, p. 778). To adequately equip social workers in the United States, educators will need to make human rights education, research, and practice a priority.

\section{References}

Acquaye, L. A., \& Crewe, S. E. (2012). International programs: Advancing human rights and social justice for African American students. Journal of Social Work Education, 48(4), 763784. https://doi.org/10.5175/JSWE.2012.201100130

Androff, D. (2016). Practicing rights: Human rights-based approaches to social work practice. Routledge.

Androff, D. (2018). Practicing human rights in social work: Reflections and rights-based approaches. Journal of Human Rights and Social Work, 3(4), 179-182. https://doi.org/10.1007/ s41134-018-0056-5

Barbera, R. A. (2006). Understanding globalization through shortterm international field experiences. The Journal of Baccalaureate Social Work, 12(1), 287-302. https://doi.org/10.18084/10847219.12.1.287
Chiarelli-Helminiak, C. M., Eggers, M., \& Libal, K. R. (2018). The integration of human rights in US social work education: Insights from a qualitative study. Journal of Human Rights and Social Work, 3(2), 99-107. https://doi.org/10.1007/ s41134-018-0050-y

Clapham, A. (2015). Human rights: A very short introduction (2nd ed.). Oxford University Press.

Council on Social Work Education. (2008). Educational policy and accreditation standards. https://www.cswe.org/getattachment/ Accreditation/Standards-and-Policies/2008-EPAS/2008EDUCAT IONALPOLICYANDACCREDITATIONSTANDARDS(EPAS)08-24-2012.pdf.aspx

Council on Social Work Education. (2015). 2015 Educational policy and accreditation standards for baccalaureate and master's social work programs. https://www.cswe.org/getattachment/ Accreditation/Accreditation-Process/2015-EPAS/2015EPAS_ Web_FINAL.pdf.aspx

Davis, A., \& Reber, D. (2016). Advancing human rights and social and economic justice: Developing competence in field education. Journal of Human Rights and Social Work, 1(3), 143-153. https:// doi.org/10.1007/s41134-016-0016-x

Gammonley, D., Rotabi, K. S., Forte, J., \& Martin, A. (2013). Beyond study abroad: A human rights delegation to teach policy advocacy. Journal of Social Work Education, 49(4), 619-634. https://doi. org/10.1080/10437797.2013.812508

Gardella, L. G. (2000). The group-centered BSW curriculum for community practice: An essay. Journal of Community Practice, 8(2), 53-69. https://doi.org/10.1300/J125v08n02_04

Global agenda for social work and social development: First reportPromoting social and economic equalities. (2014a). International Social Work, 57(4, Suppl), 3-16. https://doi.org/10.1177/ 0020872814534139

Global agenda for social work and social development: First reportPromoting social and economic equalities: North American region. (2014b). International Social Work, 57(4, Suppl), 45-49. https://doi.org/10.1177/0020872814531379

Gomez Isa, F., \& de Feyter, K. (2006). (Eds.) International protection of human rights: Achievements and challenges. University of Deusto.

Hawkins, C. A., \& Knox, K. (2014). Educating for international social work: Human rights leadership. International Social Work, 57(3), 248-257. https://doi.org/10.1177/0020872813519462

Healy, L. M. (2008). Exploring the history of social work as a human rights profession. International Social Work, 51(6), 735-748. https://doi.org/10.1177/0020872808095247

Healy, L. M., \& Link, R. J. (2012). (Eds.) Handbook of international social work: Human rights, development, and the global profession. Oxford University Press.

Healy, L. M., \& Thomas, R. L. (2020). International social work: Professional action in an interdependent world 3rd ed.). Oxford University Press.

Healy, L. M., \& Wairire, G. G. (2014). Educating for the Global Agenda: Internationally relevant conceptual frameworks and knowledge for social work education. International Social Work, 57(3), 235-247. https://doi.org/10.1177/0020872813519463

Hertel, S., \& Libal, K. (2011). (Eds.) Human rights in the United States: Beyond exceptionalism. Cambridge University Press.

Hodge, D. R. (2007). Advocating for persecuted people of faith: A social justice imperative. Families in Society: The Journal of Contemporary Social Services, 88(2), 255-262. https://doi.org/ 10.1606/1044-3894.3623

Hodge, D. R. (2010). Social justice as a unifying theme in social work education: Principles to realize the promise of a new pedagogical model. Journal of Comparative Social Welfare, 26(2-3), 201-213. https://doi.org/10.1080/17486831003687600 
Hokenstad, M. C., Healy, L. M., \& Segal, U. A. (2013). Teaching human rights: Curriculum resources for social work educators. CSWE Press.

Ife, J. (2009). Human rights from below: Achieving rights through community development. Cambridge University Press.

Ife, J. (2012). Human rights and social work: Towards rights-based practice (3rd ed.). Cambridge University Press.

International Federation of Social Workers. (2014). Global definition of social work. https://www.ifsw.org/what-is-social-work/ global-definition-of-social-work

International Federation of Social Workers. (2018). Global social work statement of ethical principles. http://ifsw.org/policies/ statement-of-ethical-principles

Jayasooria, D. (2016). Sustainable development goals and social work: Opportunities and challenges for social work practice in Malaysia. Journal of Human Rights and Social Work, 1, 19-29. https://doi.org/10.1007/s41134-016-0007-y

Kaiser, M. L., Himmelheber, S., Miller, S., \& Hayward, R. A. (2015). Cultivators of change: Food justice in social work education. Social Work Education, 34(5), 544-557. https://doi.org/10. 1080/02615479.2015.1063599

Kosher, H., Ben-Arieh, A., \& Hendlesman, Y. (2016). Children's rights and social work. Springer.

Levin, L. (2009). Human rights: Questions and answers (5th ed.). UNESCO.

Lewis, L. A., Kusmaul, N., Elze, D., \& Butler, L. (2016). The role of field education in a university-community partnership aimed at curriculum transformation. Journal of Social Work Education, 52(2), 186-197. https://doi.org/10.1080/10437797.2016.1151274

Mapp, S. (2020). Human rights and social justice in a global perspective: An introduction to international social work ( $3^{\text {rd }}$ ed.). Oxford University Press.

Mapp, S., \& Gatenio Gabel, S. (2019). The decreasing role of the USA in promoting human rights. Journal of Human Rights and Social Work, 4(2), 101-102. https://doi.org/10.1007/ s41134-019-00100-5

Mapp, S., McPherson, J., Androff, D., \& Gatenio Gabel, S. (2019). Social work is a human rights profession. Social Work, 64(3), 259-269. https://doi.org/10.1093/sw/swz023

Maschi, T. (2016). Applying a human rights approach to social work research and evaluation: A rights research manifesto. Springer.

McPherson, J. (2018). Exceptional and necessary: Practicing rights-based social work in the USA. Journal of Human Rights and Social Work, 3(2), 89-98. https://doi.org/10.1007/ s41134-018-0051-x

McPherson, J., \& Abell, N. (2012). Human rights engagement and exposure: New scales to challenge social work education. Research on Social Work Practice, 22(6), 704-713. https://doi.org/10.1177/ 1049731512454196

McPherson, J., \& Cheatham, L. P. (2015). One Million Bones: Measuring the effect of human rights participation in the social work classroom. Journal of Social Work Education, 51(1), 47-57. https://doi.org/10.1080/10437797.2015.977130

McPherson, J., \& Mazza, N. (2014). Using arts activism and poetry to catalyze human rights engagement and reflection. Social Work Education, 33(7), 944-958. https://doi.org/10.1080/02615479. 2014.885008

McPherson, J., Siebert, C. F., \& Siebert, D. C. (2017). Measuring rights-based perspectives: A validation of the Human Rights Lens in Social Work Scale. Journal of the Society for Social Work and Research, 8(2), 233-237. https://doi.org/10.1086/692017

Melekis, K., \& Woodhouse, V. (2015). Transforming social work curricula: Institutional supports for promoting sustainability. Social Work Education, 34(5), 573-585. https://doi.org/10.1080/02615479.2015.1066325

National Association of Social Workers. (2017). Code of ethics. https:// www.socialworkers.org/about/ethics/code-of-ethics
National Association of Social Workers. (2018). International policy on human rights. In Social work speaks: National Association of Social Workers policy statements 2018-2020 (11th ed., pp. 192-197). NASW Press.

Nesmith, A., \& Smyth, N. (2015). Environmental justice and social work education: Social workers' professional perspectives. Social Work Education, 34(5), 484-501. https://doi.org/10.1080/02615479. 2015.1063600

Patterson, F. M. (2004). Motivating students to work with elders: A strengths, social construction, and human rights and social justice approach. Journal of Teaching in Social Work, 24(3-4), 165-181. https://doi.org/10.1300/J067v24n03_11

Pelton, L. H. (2001). Social justice and social work. Journal of Social Work Education, 37(3), 433-439. https://doi.org/10.1080/10437797. 2001.10779065

Reichert, E. (2011a). Social work and human rights: A foundation for policy and practice ( 2 nd ed.). Columbia University Press.

Reichert, E. (2011b). Human rights in social work: An essential basis. Journal of Comparative Social Welfare, 23(3), 2007-2220. https:// doi.org/10.1080/17486831.2011.595070

Richards-Desai, S., Critelli, F., Logan-Greene, P., Borngraber, E., \& Heagle, E. (2018). Creating a human rights culture in a Master's in Social Work program. Journal of Human Rights and Social Work, 3(4), 169-178. https://doi.org/10.1007/s41134-018-0059-2

Steen, J. A. (2006). The roots of human rights advocacy and a call to action. Social Work, 51(2), 101-105. https://doi.org/10.1093/sw/ 51.2.101

Steen, J. A., Mann, M., Restivo, N., Mazany, S., \& Chapple, R. (2017). Human rights: Its meaning and practice in social work field settings. Social Work, 62(1), 9-17. https://doi.org/10.1093/sw/ sww075

Steen, J. A., \& Mathiesen, S. (2005). Human rights education: Is social work behind the curve? Journal of Teaching in Social Work, 25(34), 143-156. https://doi.org/10.1300/J067v25n03_09

Truell, R. \& Jones, D. N. (2017). Global agenda for social work and social development. Encyclopedia of Social Work. https://doi.org/ 10.1093/acrefore/9780199975839.013.1158

United Nations. (2015). Transforming our world: The 2030 agenda for sustainable development. https://www.un.org/ga/search/view_doc. asp?symbol=A/RES/70/1\&Lang $=\mathrm{E}$

United Nation's Educational, Scientific, and Cultural Organization. (1949). Human rights, comments and interpretations: A symposium. Allan Wingate.

United Nations General Assembly. (1948). Universal declaration of human rights. Paris. https://www.un.org/en/universal-declarationhuman-rights/

United Nations General Assembly. (1966). International Covenant on Civil and Political Rights, G.A. res. 2200A (XXI), 21 U.N. GAOR Supp. (No.16) at 52, U.N. Doc. A/6316 (1966), 999 U.N.T.S. 171, entered into force Mar. 23, 1976.

Witkin, S. (1994). A human rights approach to social work research and evaluation. Journal of Teaching in Social Work, 8(1-2), 239-253. https://doi.org/10.1300/J067v08n01_13

Witkin, S. (1998). Human rights and social work. Social Work, 43(3), 197-201

Witkin, S. (1999). Letter from Lapland. Social Work, 44(5), 413-415

Wronka, J. (2017). Human rights and social justice: Social action and service for the helping and health professions (2nd ed.). Sage.

Wronka, J., \& Franklin, C. (Ed.). (2019). Human rights. Encyclopedia of Social Work. Oxford University Press. https://doi.org/10.1093/ acrefore/9780199975839.013.190

Publisher's Note Springer Nature remains neutral with regard to jurisdictional claims in published maps and institutional affiliations. 